Karasu and Keeney, April 12, 2019 - bioRxiv preprint v1

\title{
Cyclin B3 is dispensable for mouse spermatogenesis.
}

\author{
Mehmet E. Karasu ${ }^{1,2}$ and Scott Keeney ${ }^{1,2,3 *}$ \\ ${ }^{1}$ Louis V. Gerstner, Jr. Graduate School of Biomedical Sciences, Memorial Sloan Kettering Cancer Center, New York, NY 10065 \\ ${ }^{2}$ Molecular Biology Program, Memorial Sloan Kettering Cancer Center, New York, NY 10065 \\ ${ }^{3}$ Howard Hughes Medical Institute, Memorial Sloan Kettering Cancer Center, New York, NY 10065 \\ * Correspondence: s-keeney@ski.mskcc.org
}

\begin{abstract}
Cyclins, as regulatory partners of cyclin-dependent kinases (CDKs), control the switch-like cell cycle transitions that orchestrate orderly duplication and segregation of genomes. Compared to mitosis, relatively little is known about how cyclin-CDK complexes control meiosis, the specialized cell division that generates gametes for sexual production. Mouse cyclin B3 was previously shown to have expression restricted to the beginning of meiosis, making it a candidate to regulate meiotic events. Indeed, female mice lacking cyclin $B 3$ are sterile because oocytes arrest at the metaphase-toanaphase transition of meiosis I. However, whether cyclin B3 functions during spermatogenesis was untested. Here, we found that males lacking cyclin $B 3$ are fertile and show no detectable defects in spermatogenesis based on histological analysis of seminiferous tubules. Cytological analysis further showed no detectable defects in homologous chromosome synapsis or meiotic progression, and suggested that recombination is initiated and completed efficiently. Moreover, absence of cyclin B3 did not exacerbate previously described meiotic defects in mutants deficient for cyclin E2, suggesting a lack of redundancy between these cyclins. Thus, unlike in females, cyclin B3 is not essential for meiosis in males despite its prominent meiosis-specific expression.
\end{abstract}

\section{Introduction}

During meiosis, one round of chromosome replication is followed by two rounds of nuclear division, which allows organisms to halve their genome content. Unique to meiosis, homologous chromosomes segregate in the first division, then sister chromatids are separated in the second division. To achieve faithful homolog separation, programmed DNA double-strand breaks (DSBs), DSB repair via homologous recombination, and formation of chiasmata between homologs must occur (Lam and Keeney 2015).

Homologous recombination is tightly regulated during meiotic prophase I. One layer of regulation is implemented by the cell cycle components, cyclins and cyclin-dependent kinases (CDKs) (Evans et al. 1983). Cyclins share a conserved domain called a "cyclin box", and are expressed and degraded in ordered fashion during the cell cycle. A wellknown function for cyclins is to regulate the activity of their catalytic binding partners, CDKs.

Cyclins with or without their CDK partners regulate various events during meiotic prophase I. For example, in Saccharomyces cerevisiae, phosphorylation of Mer2 by cyclin-CDK complexes is essential for the initiation of meiotic recombination (Henderson et al. 2006). In Tetrahymena thermophila, the meiosis-specific cyclin Cyc2p is essential for formation of the micronuclear bouquet and for homologous pairing and synapsis (Xu et al. 2019). In Caenorhabditis elegans, cyclin-related protein COSA-1 is a key component for the designation of crossover recombination products (Yokoo et al. 2012).

In mammalian meiosis, cyclins are sequentially expressed (reviewed in (Wolgemuth and Roberts 2010; Wolgemuth et al. 2013)) and genetic ablation of cyclin or CDK genes has demonstrated important roles in gametogenesis. For example, disruption of Cyclin A1 (Ccnal), which is expressed in late-prophase spermatocytes but not in somatic cells, causes arrest in late meiotic prophase and infertility in male mice (Liu et al. 1998). Mutation of Cyclin E1 (Ccne1) and Cyclin E2 (Ccne2) causes early meiotic prophase defects (Martinerie et al. 2014). In addition, mice lacking $C d k 2$ exhibit a defect in the repair of DSBs and pairing of homologous chromosomes, causing meiotic arrest and infertility (Berthet et al. 2003; Ortega et al. 2003).

Mouse Cyclin B3 (Ccnb3), an X-linked gene, is germ-line specific and is expressed in both spermatocytes and oocytes during the leptotene and zygotene stages of meiotic prophase I (Nguyen et al. 2002). The importance of the restricted expression of $C c n b 3$ was tested in a mouse model in which prolonging expression of $C c n b 3$ beyond early meiotic prophase caused abnormal spermatogenesis and increased apoptosis (Refik-Rogers et al. 2006). However, whether the absence of Ccnb3 affects spermatogenesis remained unclear.

Given the confined expression of $C c n b 3$, we hypothesized that $C c n b 3$ might regulate events during early meiotic prophase. In this study, we tested this hypothesis by generating and characterizing a mutant $C c n b 3$ allele via CRISPR-Cas9-mediated gene targeting. In separate work, we and others found that cyclin B3-deficient females are sterile (Karasu et al. 2019; Li et al. 2019). We show here, in contrast, that male mice lacking $C c n b 3$ are fertile and display little or no evidence of meiotic abnormalities. Thus, contrary to expectation, Ccnb3 is dispensable for spermatogenesis.

\section{Results}

Cyclin B3 antibody generation and cyclin B3 expression during the first wave of spermatogenesis.

The Ccnb3 locus gives rise to a $4.1 \mathrm{~kb}$ gene product, which codes for a $157.9 \mathrm{kDa}$ protein. This is an unusual size for mammalian cyclins, which are typically around $50 \mathrm{kDa}$ (Evans et al. 1983; Bloom and Cross 2007). Until now, although Ccnb3 mRNA could be detected in mammalian germ cells (Lozano et al. 2002; Nguyen et al. 2002), endogenous cyclin B3 from mouse testis extracts has not been detected due to the lack of a suitable antibody. To overcome this issue, we generated monoclonal antibodies against cyclin B3. A total of 23 monoclonal antibodies were raised against 8 different peptides (Fig 1a).

To detect endogenous cyclin B3, we used immunoprecipitation and western blotting (IP-WB). Two of the antibodies behaved well for this purpose: antibody $\# 18$ (hereafter $\mathrm{mAb}^{\mathrm{N}}$ ) raised against a more $\mathrm{N}$ terminal peptide (aa 110-123) and antibody \#5 (hereafter $\mathrm{mAb}^{\mathrm{C}}$ ) raised against a more C-terminally located peptide (aa 1067-1080) (Fig 1a). IP-WB with these antibodies detected endogenous cyclin B3 from wildtype testis extracts but not spleen tissue extracts (Fig 1b). The protein migrated as a doublet at $\sim 150 \mathrm{kDa}$. The slower-migrating band may represent post-translational modification.

To gain further insights into $C c n b 3$ expression, we collected testes from wild-type males during the first wave of meiosis at $6,10,12$, and 16 days postpartum (dpp) and analyzed mRNA levels by reversetranscription quantitative PCR (RT-qPCR). Ccnb3 expression was at minimal or background levels at $6 \mathrm{dpp}$, when seminiferous tubules 
contain only somatic cells and spermatogonia (the first wave of spermatogenesis begins around $7 \mathrm{dpp}$ in mice (Bellvé et al. 1977)). Ccnb3 signal was readily detected at $10 \mathrm{dpp}$ and was highest at $12 \mathrm{dpp}$ (Fig 1c), when seminiferous tubules are mostly populated with leptotene and zygotene cells (Bellvé et al. 1977). This result agrees with a previous study (Nguyen et al. 2002) and published testis RNA-seq data (Margolin et al. 2014).

Cyclin B3 protein was detected in testis extracts from 16-dpp but not 6-dpp males, confirming that cyclin B3 protein is attributable to spermatocytes (Fig 1d). Unfortunately, we have been unable to detect the protein by immunofluorescent staining of meiotic spreads or squashes (data not shown). Nevertheless, these experiments provide the first direct confirmation of the presence of cyclin B3 protein in early meiotic cells.

\section{Targeted mutation of Ccnb3}

To address whether cyclin B3 has a role during spermatogenesis, we generated endonuclease mediated (em) mutations by CRISPR-Cas9mediated genome editing. We used a guide RNA to target the 3' end of the $2.7-\mathrm{kb}$ long exon 7 . Among the founder animals, several out-offrame alleles were identified (Fig 2a). We focused on the $C c n b 3^{\text {emI }}$ allele (hereafter $C_{c n b 3^{-}}$), which has a 14-bp deletion causing a frameshift and premature stop codon upstream of the cyclin box, which is encoded in exons 9-13. We reported elsewhere that the mutant mice are viable with no apparent somatic defects (Karasu et al. 2019).

In principle, the $C c n b 3^{-}$allele could produce a C-terminally truncated protein of 1090 aa $(\sim 123 \mathrm{kDa})$. When recombinant cyclin B3 was expressed in E. coli, blotting with $\mathrm{mAb}^{\mathrm{N}}$ detected both full length protein and the shorter form expressed from a construct mimicking the em1 allele (Fig $\mathbf{2 b}$ ). Full length protein but not the truncated form could be detected with $\mathrm{mAb}^{\mathrm{C}}$ (Fig 2b), as expected because the deletion mutation destroys the epitope recognized by this antibody (Fig 1a). Zebrafish cyclin B3 was not detected with either antibody raised against the mouse protein, confirming specificity (Fig $\mathbf{2 b}$ ). Interestingly, a commercial anti-cyclin B3 antibody used in a recent study (Tang et al. 2018) failed to detect the recombinant proteins under these conditions (Fig 2b, right panel), suggesting that caution is warranted when using this reagent.

To address whether the C-terminally truncated protein was present in $C c n b 3^{-/ Y}$ spermatocytes, we performed IP-WB experiments using $\mathrm{mAb}{ }^{\mathrm{N}}$. Testis extracts from $C \mathrm{cnb} 3^{-/ Y}$ mutants failed to yield signal above background for either the full length or truncated product (Fig 2c). We cannot exclude the possibility that low levels of the truncated protein are present, but these results suggest that the truncated form is unstable in vivo if it is made at all. We could not test whether a Cterminal portion of the protein downstream of the mutation is expressed because of lack of a suitable antibody.

Analysis of $C c n b 3 \mathrm{mRNA}$ levels by RT-qPCR showed an $\sim 10$-fold decrease in $\mathrm{Ccnb3}^{-/ Y}$ mutants compared to wild-type littermates (Fig 2d). This decrease may be caused by nonsense-mediated decay and provides further support that the em 1 allele is at least a severe loss-offunction allele.

\section{Ccnb3 ${ }^{-/ Y}$ males do not show gross defects in spermatogenesis or meiotic prophase progression.}

Problems during spermatogenesis typically lead to sterility or reduced fertility, reduced testis weight, and/or seminiferous tubule abnormalities (de Rooij and de Boer 2003). To address whether Ccnb3

${ }^{Y Y}$ males are fertile, males were placed in cages with wild-type females for two months. $C c n b 3^{-/ Y}$ males and their wild-type littermates sired similar numbers of progeny (totals during this breeding period of 30 and 27 pups, respectively, sired from two females each). Furthermore, adult $\mathrm{Ccnb}^{-Y Y}$ males were indistinguishable from their wild-type littermates for testis/body weight ratio (Fig 3a, $p=0.14$, Student's t-test) and in histological appearance of seminiferous tubule sections (Fig 3b). Seminiferous tubules from $C c n b 3^{-/ Y}$ contained the full array of spermatogenic cells including spermatogonia, spermatocytes, and round and elongated spermatids (Fig 3b). Thus, spermatogenesis is not grossly impaired in the absence of Ccnb3.

To test for more subtle meiotic defects, we immunostained meiotic chromosome spreads. In meiotic prophase, cells can be classified into four different cytological stages; leptonema, zygonema, pachynema and diplonema. The transition between each stage can be followed by the changes in the staining pattern of components of the synaptonemal complex (SC) (de Vries et al. 2005; Fraune et al. 2012). SYCP3, a component of the axial elements of the SC, appears as dots or short patches in leptonema. During zygonema, SYCP3-containing axes elongate and SYCP1, which forms the transverse filaments of the SC, starts to appear. The SC is present between homologs along their entire length during pachynema, then the SC disassembles in diplonema. We followed SC formation and disassembly in $\mathrm{Ccnb3}^{-/ Y}$ males and their wild type littermates by staining chromosome spreads with antibodies to SYCP3 and SYCP1. We did not observe any aberrant SC formation or defects in disassembly (Fig 4a).

\section{Ccnb3 ${ }^{-/ Y}$ spermatocytes are recombination proficient.}

We used cytological markers to evaluate the formation and repair of meiotic DSBs. $\gamma \mathrm{H} 2 \mathrm{AX}$ is a phosphorylated form of the histone variant $\mathrm{H} 2 \mathrm{AX}$ that accumulates upon formation of DSBs (Mahadevaiah et al. 2001). In wild-type mice, $\gamma \mathrm{H} 2 \mathrm{AX}$ appears during leptonema then disappears from the autosomes as DSBs are repaired, leaving $\gamma \mathrm{H} 2 \mathrm{AX}$ signal only in the sex body, a heterochromatic domain containing the sex chromosomes visible during pachynema and diplonema (Mahadevaiah et al. 2001; Barchi et al. 2005). $\gamma \mathrm{H} 2 \mathrm{AX}$ appearance and disappearance were similar in $C c n b 3^{-/ Y}$ males and their wild-type littermates (Fig 4b). Defects in meiotic DSB repair often manifest as persistent patches of $\gamma \mathrm{H} 2 \mathrm{AX}$ along fully synapsed chromosomes in late pachynema and desynapsing chromosomes in diplonema (Roig et al. 2010; Pacheco et al. 2015; Marcet-Ortega et al. 2017). Absence of such patches in $C c n b 3^{-/ Y}$ males $(\mathrm{n}=23$ cells examined) suggests that DSB repair is completed normally.

We also counted the number of cells at different stages of meiotic prophase using $\gamma \mathrm{H} 2 \mathrm{AX}$ and SYCP3 staining (Fig 4c). The distribution of cell stages was indistinguishable between $C \mathrm{Cnb} 3^{-/ Y}$ males and their wild-type littermates $(p=0.95$, chi-square test), further confirming that meiotic progression is affected little if at all by disruption of cyclin B3 expression.

We also counted the number of foci of the strand exchange protein, $\mathrm{DMC}$; these foci are maximal at early-to-mid zygonema and then decrease as DSBs are repaired via homologous recombination (Moens et al. 2002). $C c n b 3^{-/ Y}$ males displayed overall similar numbers and temporal progression of DMC1 foci as their wild-type littermates, except that they had a significant but quantitatively modest elevation in focus numbers in late zygonema and early-to-mid pachynema (Fig 5a). Lastly, we counted MLH1 foci, which mark nascent crossover sites from mid-to-late pachynema (Gray and Cohen 2016). The Ccnb3 ${ }^{-/ Y}$ males showed a slight increase in MLH1 foci compared to their wildtype littermates (means of 25 foci in wild type vs. 26 foci in $C c n b 3^{-/ Y}$ ) (Fig 5b). Overall, these data suggest that Ccnb3 is largely if not completely dispensable for initiation and completion of meiotic recombination, although it may contribute modestly to control of the amount or timing of recombination (see Discussion).

\section{Evaluating potential redundancy with other cyclins}

During spermatogenesis, approximately thirty cyclins and cyclinrelated genes are present in different cell populations (Malumbres and Barbacid 2005; Malumbres and Barbacid 2009; Margolin et al. 2014), raising the possibility of redundancy between $C c n b 3$ and other cyclins. 
Karasu and Keeney, April 12, 2019 - bioRxiv preprint v1

For example, deletion of Ccne2 (encoding cyclin E2) causes upregulation of Ccnel mRNA and cyclin E1 protein levels, which compensates for the absence of Ccne2 during spermatogenesis (Martinerie et al. 2014). Likewise, Ccne2 is upregulated in a Ccnel mutant, which compensates for the absence of Ccnel (Martinerie et al. 2014). To address whether a similar phenomenon occurs in $C c n b 3^{-/ Y}$ males, we quantified testis mRNA levels of a panel of cyclins by RTqPCR. We found that Ccna2 levels were decreased by $\sim 30 \%$ whereas others were unchanged (Fig 6a). Importantly no upregulation was detected among the tested cyclins. While these results do not rule out the possibility that one of these cyclins exerts a redundant role with $C c n b 3$, the findings suggest that compensatory misregulation such as seen between Ccnel and Ccne 2 is not responsible for the lack of meiotic defect in cyclin B3-deficient spermatocytes.

We next considered the possibility that E-type cyclins might substitute for $C c n b 3$ because they are present during overlapping portions of meiotic prophase, particularly Ccne2 (Martinerie et al. 2014). Testis size is reduced in $C c n e 2^{-/}$mice because spermatocytes arrest in diplonema, with a fraction of cells displaying abnormal synapsis during pachynema (Geng et al. 2003; Martinerie et al. 2014). In $\mathrm{Ccne}^{-/-} \mathrm{Ccne}^{-/-}$double mutant mice, spermatocytes arrest in a pachytene-like stage with severe pairing and synapsis defects (Martinerie et al. 2014). We asked whether the combined deletion of $C c n e 2$ and $C c n b 3$ would lead to synergistic defects in spermatogenesis. However, introducing the Ccnb3 mutation did not further exacerbate the reduced testis size in $C_{c n e} 2^{-/-}$mutants (Fig 6b, $\mathrm{p} \geq 0.98$, Student's t-test ). Staining meiotic spreads for SYCP1 and SYCP3 (Fig 6c) revealed examples of synaptic anomalies in $\mathrm{Ccne}^{-/-} \mathrm{Ccnb}^{-/ Y}$ spermatocytes as previously reported for $C c n e 2^{--}$mutants, and also showed that double mutant spermatocytes could progress through pachynema and reach diplonema, as in $\mathrm{Ccne}^{-/-}$(Martinerie et al. 2014). These results indicate that the mutation of $C c n b 3$ has no additive effect on the phenotype of Ccne2 mutants, suggesting in turn that cyclin E2 does not compensate for the absence of cyclin B3.

\section{$\mathrm{Ccnb}^{-/ Y}$ spermatocytes do not show gross abnormality in the metaphase-to-anaphase I transition.}

Similar to spermatocytes, oocytes deficient for cyclin B3 show no apparent defects in meiotic prophase I (Karasu et al. 2019; Li et al. 2019). However, cyclin B3 is essential for the metaphase-to-anaphase I transition in oocytes. Ccnb3 $3^{-/-}$oocytes arrest in metaphase I with compromised activity of the anaphase promoting complex/cyclosome (APC/C), which leads to inefficient degradation of the $\mathrm{APC} / \mathrm{C}$ substrates cyclin B1 and securin and no active separase (Karasu et al. 2019; Li et al. 2019). Our results thus far showed no evidence of metaphase arrest in cyclin B3-deficient spermatocytes, as judged by the normal size of $C c n b 3^{-/ Y}$ testes (Fig 3a) and normal appearance of stage XII tubules (Fig $\mathbf{3 b}$; tubules of this type contain meiotically dividing spermatocytes). However, to more rigorously assess whether $C \mathrm{Cnb} 3^{-/ Y}$ spermatocytes experience a delayed metaphase-to-anaphase transition, we determined the number of stage XII tubules. Defects in the MI-toMII transition can elevate the fraction of stage XII tubules (Papanikos et al. 2018). Testis sections were stained with antibodies against histone H3 phoshorylated on serine 10 (pH3) (Jain et al. 2018) (Fig 7a). The percentage of tubules that were at stage XII was similar between wild type and $C c n b 3^{-/ Y}$, suggesting that mutant spermatocytes do not reside longer in metaphase I during spermatogenesis (Fig 7b). These results lead us to infer that $\mathrm{APC} / \mathrm{C}$ activity is likely not substantially compromised in spermatocytes lacking cyclin B3, unlike in oocytes.

\section{Discussion}

Despite prominent, regulated expression during spermatogenesis,
Ccnb3-deficient males are fully fertile and exhibit no gross meiotic abnormalities. While we cannot exclude the possibility that the em 1 allele retains partial $C c n b 3$ function, our molecular characterization of mRNA and protein expression in testes (this study) and the strong metaphase I arrest in homozygous mutant oocytes (Karasu et al. 2019) show that this allele is at least a substantial loss-of-function mutation. Furthermore, an independently generated $C c n b 3$ mutation that similarly causes oocyte arrest was also reported to support normal male fertility (Li et al. 2019). Taken together, these findings strongly suggest that cyclin B3 is dispensable for male meiosis. The basis of the extreme sexual dimorphism in the requirement for cyclin B3 is thus far unclear. Null Ccnb3 mutations in Drosophila melanogaster also do not affect male fertility (Jacobs et al. 1998), although differences in meiosis in male flies such as lack of recombination (McKee et al. 2012) raised the possibility that the genetic requirement could have been different in mice.

Based on its expression timing, we originally speculated that $C c n b 3^{-Y Y}$ males might have defects in processes important for meiotic recombination, such as DSB formation. If so, we would have expected a similar phenotype to mice that lack or have reduced activity of essential DSB proteins, including the Spo 11, Mei4, Mei1, Iho1, Top6bl knock out animals (Baudat et al. 2000; Libby et al. 2002; Kumar et al. 2010; Kauppi et al. 2011; Kauppi et al. 2013; Robert et al. 2016; Stanzione et al. 2016). Another possibility might have been that $C c n b 3$ contributes to later events, in which case we might have expected phenotypes similar to animals lacking Ccnel or $C d k 2$ (Geng et al. 2003; Martinerie et al. 2014). However, $C c n b 3^{-/ Y}$ mice did not show any obvious defects associated with spermatogenesis, although we did observe a modest elevation of foci of RAD51 and MLH1. It is possible that this elevation is not biologically meaningful. For example, there could be slight differences in strain background between $C_{c n b} 3^{-/ Y}$ mice and the controls because of incomplete backcrossing, or there could be small differences between the samples in terms of enrichment for slightly later or slightly earlier cells within the scored substages of meiotic prophase. However, it is also possible that cyclin B3 contributes modestly to regulating how quickly recombination is completed. Alternatively, absence of cyclin B3 may allow cells to continue forming DSBs past the time they normally would have stopped. Importantly, however, the absence of $\gamma \mathrm{H} 2 \mathrm{AX}$ patches in late pachynema or diplonema and the apparently normal meiotic progression of $\mathrm{Ccnb}^{-/ Y}$ spermatocytes strongly indicate that cyclin B3 is largely if not completely dispensable for completion of recombination.

It is intriguing that a gene specifically expressed in testis and whose temporal expression in male mice is confined to meiotic prophase appears not to contribute to meiosis or spermatogenesis in any substantive manner. However, a recent study reported the generation of knock-out mutations for 54 testis-specific genes, all of which yielded fertile mice (Miyata et al. 2016). It could be that all or most of these genes are not important at all for reproductive success, but an interesting alternative is that their functions are context dependent. It should be noted that nearly all experiments to date have been conducted with inbred laboratory mice that are not under stress or reproductive competition. These experiments may therefore fail to capture biological functions that would manifest in more natural conditions. For example, one of the 54 genes knocked out by Miyata and colleagues was the polycystin family receptor for egg jelly, Pkdrej. Pkdrej-deficient males were as fertile as their wild-type littermates in unrestricted mating trials, but they performed poorly when competing with wild type in sequential mating trials and in artificial insemination of mixed-sperm populations, indicating that Pkdrej is important in postcopulatory reproductive selection (Sutton et al. 2008). In light of findings such as this, it may be interesting to query the effects of $C c n b 3$ mutations in different strain backgrounds or in more complex mating scenarios that are more akin to reproductive challenges faced in natural environments. 


\section{Materials and Methods}

\section{Animals:}

Mice in the Keeney lab were maintained and sacrificed for the experiments under regulatory standards approved by the Memorial Sloan Kettering Cancer Center (MSKCC) Institutional Animal Care and Use Committee. Animals were fed regular rodent chow with ad libitum access to food and water.

\section{Antibody production:}

Mouse monoclonal antibodies directed against mouse cyclin B3 were produced by Abmart Inc. (Shanghai) using synthetic peptides of the sequences shown in Fig 1. Ascites from different immunization clones were first tested by western blotting against recombinant cyclin B3 protein expressed in E. coli from the pGKBT7 vector (Clontech). Clones that recognized the recombinant protein were tested for their efficiency in immunoprecipitating recombinant cyclin B3. Hybridoma cell lines were generated for $\mathrm{mAb} \mathrm{b}^{\mathrm{C}}$ and $\mathrm{mAb}$ antibodies and were maintained in the Antibody and Bioresource Core Facility at MSKCC. Cell culture supernatants from the cell lines were subjected to protein $\mathrm{G}$ purification to enrich monoclonal antibodies and antibodies were stored in phosphatebuffered saline (PBS) at $-20^{\circ} \mathrm{C}$.

\section{Immunoprecipitation and western blotting from testis extracts:}

For mouse testis extracts, dissected testes were placed in an Eppendorf tube, frozen on dry ice, and stored at $-80^{\circ} \mathrm{C}$. The frozen tissue was suspended in RIPA buffer $(50 \mathrm{mM}$ Tris- $\mathrm{HCl} \mathrm{pH} 7.5,150 \mathrm{mM} \mathrm{NaCl}, 0.1 \%$ SDS, $0.5 \%$ sodium deoxycholate, $1 \%$ NP40) supplemented with protease inhibitors (Roche Mini tablets). The tissue was disrupted with a plastic pestle and incubated by endover-end rotation for 15 minutes at $4^{\circ} \mathrm{C}$. After brief sonication, samples were centrifuged at $15000 \mathrm{rpm}$ for 15 minutes. The clear lysate was transferred to a new tube and used for immunoprecipitation.

Testis extract was pre-cleared with protein G Dynabeads (Thermofisher) by end-over-end rotation for $1 \mathrm{hr}$ at $4^{\circ} \mathrm{C}$. Antibodies were added to pre-cleared lysates and incubated overnight with end-over-end rotation at $4^{\circ} \mathrm{C}$. Protein $\mathrm{G}$ Dynabeads were added to the tubes and incubate for $1 \mathrm{hr}$ with end-over-end rotation at $4{ }^{\circ} \mathrm{C}$. Beads were washed three times with RIPA buffer, resuspended in 1x NuPAGE LDS sample buffer (Invitrogen) with $50 \mathrm{mM}$ DTT, and boiled 5 minutes to elute immunoprecipitated proteins.

Immunoprecipitated samples were separated on $4-12 \%$ Bis-Tris NuPAGE precast gels (Life Technologies) at $150 \mathrm{~V}$ for 70 minutes. Proteins were transferred to polyvinylidene difluoride (PVDF) membranes by wet transfer method in Tris-glycine- $20 \%$ methanol at $120 \mathrm{~V}$ for 40 minutes at $4^{\circ} \mathrm{C}$. Membranes were blocked with $5 \%$ non-fat milk in PBS- $0.1 \%$ Tween (PBS-T) for 30 minutes at room temperature on an orbital shaker. Blocked membranes were incubated with primary antibodies $1 \mathrm{hr}$ at room temperature or overnight at $4^{\circ} \mathrm{C}$. Membranes were washed with PBS-T for 30 minutes at room temperature, then incubated with horseradish peroxidase (HRP)-conjugated secondary antibodies for $1 \mathrm{hr}$ at room temperature. Membranes were washed with PBS-T for 15 minutes and the signal was developed by ECL Plus (Perkin Elmer) or ECL Prime (GE Healthcare)

\section{CRISPR-Cas9 mediated gene targeting and mouse genotyping:}

Ccnb3 mutations were generated by the MSKCC Mouse Genetics Core Facility. Exon 7 was targeted by guide RNA (C40TGAACTTGGCATGATAGCAC). Guide RNA was cloned into pDR274 vector for in vitro transcription. In vitro transcribed guide RNA (10 ng/ $\mu$ l) and Cas9 (20 $\mathrm{ng} / \mu \mathrm{l}$ ) were microinjected using conventional techniques (Romanienko et al. 2016) into pronuclei of $\mathrm{CBA} / \mathrm{J} \times \mathrm{C} 57 \mathrm{BL} / 6 \mathrm{~J}$ F2 hybrid zygotes generated by crossing CBAB6F $1 / \mathrm{J}$ hybrid females with $\mathrm{C} 57 \mathrm{BL} / 6 \mathrm{~J}$ males.

Genomic DNA from founder animals was subjected to PCR by using primers CCN3B-A and CCN3B-B (all primer sequences are in Supplemental Table S1) under the following conditions: 3 minutes at $94^{\circ} \mathrm{C}$; then 35 cycles of 15 seconds at $94^{\circ} \mathrm{C}, 90$ seconds at $68^{\circ} \mathrm{C}$; then a final extension for 3 minutes at $68^{\circ} \mathrm{C}$. T7 endonuclease I digestion was performed to identify the animals carrying insertion/deletion mutations (indels) (Guschin et al. 2010). Because males have only one copy of the X-linked Ccnb3 gene, the PCR amplification and T7 assay on male founders was performed in the presence of wild-type genomic DNA.

To define the molecular nature of indels, genomic DNA from T7-positive animals was amplified using the primers indicated above. Amplification products were used for $\mathrm{TA}$ Cloning (TA Clonining ${ }^{\mathrm{TM}}$ Kit with $\mathrm{pCR}^{\mathrm{TM}} 2.1$ vector, Invitrogen). Ten white bacterial colonies were selected and inserts were sequenced. The $\mathrm{em} /$ allele, an out of frame deletion, was chosen to generate the $C c n b 3^{\text {em ISky }}$ line. After two rounds of backcrossing to C57BL/6J, animals were interbred to generate homozygous and heterozygous female animals and hemizygous male animals.

Primers for genotyping were GT4-F and GT4-R. The PCR was performed under following conditions: 2 minutes at $94^{\circ} \mathrm{C}$; then 35 cycles of 20 seconds at $94^{\circ} \mathrm{C}, 30$ seconds at $54^{\circ} \mathrm{C}$ and 30 seconds at $72^{\circ} \mathrm{C}$; then a final extension 3 minutes at $72^{\circ} \mathrm{C}$. The amplification product $(202 \mathrm{bp})$ was subjected to Bsrl enzyme digestion (NEB). The wild-type sequence is cut to yield two fragments of 103 and $99 \mathrm{bp}$; the BsrI site is lost in the eml allele.

For cyclin E genotyping, the published protocol was followed (Martinerie et al. 2014). Briefly, the following primers were mixed and used for PCR: E2-L, E2-G, and EN-3. The PCR was performed as follows: 2 minutes at $94^{\circ} \mathrm{C}$; then 35 cycles of 20 seconds at $94^{\circ} \mathrm{C}, 30$ seconds at $54^{\circ} \mathrm{C}$ and 30 seconds at $72^{\circ} \mathrm{C}$; then a final extension 3 minutes at $72^{\circ} \mathrm{C}$. The PCR products are $400 \mathrm{bp}$ for the wildtype allele and $300 \mathrm{bp}$ for the mutant allele. Further genotyping was performed by PCR with primers E2-3 and E2-4 using the following conditions: 2 minutes at $94^{\circ} \mathrm{C}$; then 35 cycles of 20 seconds at $94^{\circ} \mathrm{C}, 30$ seconds at $54^{\circ} \mathrm{C}$ and 30 seconds at $72^{\circ} \mathrm{C}$; then a final extension 3 minutes at $72^{\circ} \mathrm{C}$. A 223 bp PCR product is recovered from wild type; absence of PCR product indicates the mutant.

\section{Spermatocyte meiotic spread preparation:}

Primary and secondary antibodies are listed in Supplemental Table S2. Testes were dissected and deposited after removal of the tunica albuginea in 50 $\mathrm{ml}$ Falcon tubes containing $2 \mathrm{ml}$ TIM buffer $(104 \mathrm{mM} \mathrm{NaCl}, 45 \mathrm{mM} \mathrm{KCl}, 1.2$ $\mathrm{mM} \mathrm{MgSO} 4,0.6 \mathrm{mM} \mathrm{KH}_{2} \mathrm{PO}_{4}, 6.0 \mathrm{mM}$ sodium lactate, $1.0 \mathrm{mM}$ sodium pyruvate, $0.1 \%$ glucose $) .200 \mu l$ collagenase $(20 \mathrm{mg} / \mathrm{ml}$ in TIM buffer) was added, and left shaking at $550 \mathrm{rpm}$ for 55 minutes at $32^{\circ} \mathrm{C}$. After incubation, TIM buffer was added to a final volume of $15 \mathrm{ml}$, followed by centrifugation for $1 \mathrm{~min}$ at $600 \mathrm{rpm}$ at room temperature. Separated tubules were washed 3 times in TIM buffer. Then, separated tubules were resuspended in $2 \mathrm{ml}$ TIM, with $200 \mu \mathrm{l}$ trypsin $(7 \mathrm{mg} / \mathrm{ml}$ in TIM) and $20 \mu \mathrm{l}$ DNase I (400 $\mu \mathrm{g} / \mathrm{ml}$ in TIM buffer) and incubated for 15 minutes at $32^{\circ} \mathrm{C}$ at $550 \mathrm{rpm}$ in a thermomixer. $500 \mu \mathrm{l}$ trypsin inhibitor $(20 \mathrm{mg} / \mathrm{ml}$ in TIM) and $50 \mu \mathrm{l}$ DNase I solution were added and mixed. A wide mouthed plastic Pasteur pipette or P1000 pipette was used to disperse the tissue further by pipetting up and down for 2 minutes. Cells were passed through a 70- $\mathrm{mm}$ cell strainer into a new $50 \mathrm{ml}$ Falcon tube. TIM was added to a final volume of $15 \mathrm{ml}$ and mixed. Cells were centrifuged for 5 minutes at $1200 \mathrm{rpm}$. Supernatant was removed, $15 \mu \mathrm{l}$ DNase I solution was added and gently mixed, followed by $15 \mathrm{ml}$ TIM. Washing with TIM and resuspension in the presence of DNase I was repeated 3 times. Single-cell suspension was pelleted and resuspended in TIM according to original weight ( $200 \mathrm{mg}$ in $400 \mu \mathrm{l}) .10 \mu \mathrm{l}$ of cell suspension was added to $90 \mu \mathrm{l}$ of $100 \mathrm{mM}$ sucrose solution, flicked three times and incubated for 8 minutes at room temperature.

Superfrost glass slides were divided in two squares by use of Immedge pen. Each square received $100 \mu 1 \%$ paraformaldehyde (PFA) (freshly dissolved in the presence of $\mathrm{NaOH}$ at $65^{\circ} \mathrm{C}, 0.15 \%$ Triton, $\mathrm{pH} 9.3$, cleared through $0.22 \mu \mathrm{m}$ filter) and $45 \mu 1$ of cell suspension was added per square, swirled three times, and dried in a closed slide box for 3 hours, followed by drying with half-open lid 1.5 hours at room temperature. Slides were washed in a Coplin jar $2 \times 3$ minutes in milli-Q water on a shaker, $1 \times 5$ minutes with $0.4 \%$ PhotoFlo, air dried and stored in aluminum foil at $-80^{\circ} \mathrm{C}$.

For staining, slides were washed with PBS and blocked with blocking buffer (PBS with $0.3 \%$ bovine serum albumin (BSA)) for 30 minutes at room temperature. Slides were incubated with primary antibodies overnight at $4{ }^{\circ} \mathrm{C}$. Slides were washed with PBS-T three times for 10 minutes and then incubated with the secondary antibodies for $1 \mathrm{hr}$ at room temperature. The slides were further washed with PBS-T three times in the dark before air drying and mounting with Vectashield containing 4',6-diamidino-2-phenylindole (DAPI).

Images of spread spermatocytes were acquired on a Zeiss Axio Observer Z1 Marianas Workstation, equipped with an ORCA-Flash 4.0 camera, illuminated by an X-Cite 120 PC-Q lightsource, with either $63 \times 1.4 \mathrm{NA}$ oil immersion objective or $100 \times 1.4$ NA oil immersion objective. Marianas Slidebook (Intelligent Imaging Innovations, Denver Colorado) software was used for acquisition.

\section{Total mRNA extraction, cDNA library generation and RT-qPCR:}

Testes were dissected and frozen on dry ice. Total mRNA was extracted using RNeasy Plus Mini Kit (QIAGEN, 74134) following the manufacturer's instructions. Superscript ${ }^{\mathrm{TM}}$ III First-Strand Synthesis SuperMix (Invitrogen, 18080400) was used with oligo dT primers to generate testis cDNA, which was 
diluted 1:10 to be used in RT-qPCR carried out using LightCycler 480 SYBR Green I Master (Roche, 4707516001) under the following conditions: 10 minutes at $95^{\circ} \mathrm{C}$; then 45 cycles of 10 seconds at $95^{\circ} \mathrm{C}, 20$ seconds at $55^{\circ} \mathrm{C}$ and 10 seconds at $72^{\circ} \mathrm{C}$. Amplification products were detected on the LightCycler 480 II Real-Time PCR instrument (Roche). LightCycler 480 Software was used to quantify products by absolute quantification analysis using the second derivative maximum method. All reactions were done in triplicate and the mean of crossing point $(\mathrm{Cp})$ value were used for the analysis. $\mathrm{Cp}$ values were normalized to the value obtained for $B 2 M$ reactions $(\Delta \mathrm{Cp})$. Then, the differences between knockout and wild-type samples were calculated for each primer set $(\Delta \Delta \mathrm{Cp})$ and the fold change (knockout vs wild type) was calculated as $2^{-{ }_{n} \mathrm{Cp}}$. Primers used for RTqPCR are listed in Supplemental Table S1.

\section{Plasmids:}

Mouse $C c n b 3$ mRNA was amplified by PCR from whole testis cDNA and cloned into modified pGBKT7 vector to express in yeast. Vectors for expression of cyclin B3 (wild type, $\Delta 14$ bp mutant or zebrafish) N-terminally tagged with SUMO protein and $6 \times$ histidine were generated by cloning into modified pRSFDUET vector (gift from E. Wasmuth, MSKCC). To generate the $\Delta 14$ bp mutation, PCR primers that delete the same base pairs that are deleted in the $C c n b 3^{-}$allele were used to amplify pRSF-Duet-Ccnb3, and the resulting PCR product was phosphorylated and ligated. Primers are listed in Supplemental Table S1.

\section{Expression of recombinant cyclin B3 in E.coli.}

The expression vectors described above were used to produce recombinant cyclin B3. Briefly, E. coli strain BL21 was transformed with the expression vector and a single colony was picked to inoculate liquid LB overnight at $37^{\circ} \mathrm{C}$. The overnight culture was diluted to $\sim 0.04\left(\mathrm{OD}_{600}\right)$ and once the $\mathrm{OD}_{600}$ had reached $\sim 0.6$, the protein expression was induced by addition of $1 \mathrm{mM}$ isopropyl $\beta$-D-1-thiogalactopyranoside (IPTG) for $2 \mathrm{hr}$ at $37^{\circ} \mathrm{C}$. Cells were harvested by centrifugation at $6000 \mathrm{~g}, 15 \mathrm{~min}$. All further steps were executed at $4^{\circ} \mathrm{C}$. Pellets were resuspended in lysis buffer (50 mM HEPES-NaOH pH 8.0, $300 \mathrm{mM} \mathrm{NaCl}$, $0.1 \mathrm{mM}$ dithiothreitol (DTT), $10 \%$ glycerol, and $20 \mathrm{mM}$ imidazole). The sample was sonicated 3 times 10 seconds on-off, $20 \%$ duty cycle. The solution was cleared by centrifugation at 15,000 rpm, 20 minutes. The clear protein lysate was mixed with sample loading buffer and analyzed by SDS-PAGE or used for WB.

\section{Histology:}

Fixation, tissue processing, and staining were performed as described (Jain et al. 2018). Testes from adult mice were fixed overnight in $4 \%$ PFA at $4{ }^{\circ} \mathrm{C}$. PFA-fixed tissues were washed for $1 \mathrm{hr}$ in water at $4^{\circ} \mathrm{C}$. Fixed tissues were stored in $70 \%$ ethanol for up to 5 days prior to embedding in paraffin and sectioning ( $5 \mu \mathrm{m}$ for testes). The tissue sections were deparaffinized with EZPrep buffer (Ventana Medical Systems) and antigen retrieval was performed with CC1 buffer (Ventana Medical Systems). Sections were blocked for 30 min with Background Buster solution (Innovex), followed by avidin-biotin blocking for 8 min (Ventana Medical Systems). Periodic acid Schiff (PAS) staining was performed by the MSKCC Molecular Cytology Core Facility using the

\section{$\underline{\text { References }}$}

Ahmed EA, de Rooij DG (2009) Staging of mouse seminiferous tubule crosssections. Methods Mol Biol. 558:263-277 doi:10.1007/978-1-60761-1035 16

Barchi M et al. (2005) Surveillance of different recombination defects in mouse spermatocytes yields distinct responses despite elimination at an identical developmental stage. Mol. Cell. Biol. 25:7203-7215 doi:10.1128/MCB.25.16.7203-7215.2005

Baudat F, Manova K, Yuen JP, Jasin M, Keeney S (2000) Chromosome synapsis defects and sexually dimorphic meiotic progression in mice lacking Spo11. Mol Cell. 6:989-998 doi:10.1016/S1097-2765(00)00098-8

Bellvé AR, Cavicchia JC, Millette CF, O'Brien DA, Bhatnagar YM, Dym M (1977) Spermatogenic cells of the prepuberal mouse. Isolation and morphological characterization. J. Cell Biol. 74:68-85 doi:10.1083/jcb.74.1.68

Berthet C, Aleem E, Coppola V, Tessarollo L, Kaldis P (2003) Cdk2 knockout mice are viable. Curr. Biol. 13:1775-1785

Bloom J, Cross FR (2007) Multiple levels of cyclin specificity in cell-cycle
Autostainer XL (Leica Microsystems, Wetzlar, Germany) automated stainer for PAS with hematoxylin counterstain and coverslips were mounted with Permount (Fisher Scientific). For immunofluorescent staining, slides were deparaffinized with EZPrep buffer (Ventana Medical Systems), antigen retrieval was performed with CC1 buffer (Ventana Medical Systems), and slides were blocked for 30 minutes with background buster solution (Innovex, Richmond, California). For staining phospho-Histone H3 (Ser10), avidin-biotin blocking (Ventana Medical Systems) was performed for 8 minutes. Slides were incubated with the primary antibody (rabbit anti-pH3) for 5 hours, followed by 60 minutes incubation with biotinylated goat anti rabbit antibodies. Streptavidin-HRP D (Ventana Medical Systems) was used for detection followed by incubation with Tyramide Alexa Fluor 594 (Invitrogen, Carlsbad, California). After staining, slides were counterstained with $5 \mu \mathrm{g} / \mathrm{ml}$, DAPI (Sigma, Damstadt, Germany) for 10 minutes and mounted with coverslips with Mowiol. PAS-stained slides were digitized using Panoramic Flash Slide Scanner (3DHistech, Budapest, Hungary) with a $20 \times 0.8$ NA objective (Carl Zeiss, Jena, Germany). Images were produced and analyzed using the Panoramic Viewer software (3DHistech). Immunofluorescence images for $\mathrm{pH} 3$ staining were captured by a Zeiss Axio Observer Z1 Marianas Workstation, equipped with an ORCA-Flash 4.0 camera, illuminated by an X-Cite 120 PC-Q lightsource, either with 10 or $40 \times 1.4$ NA objective. Marianas Slidebook (Intelligent Imaging Innovations, Denver Colorado) software was used for acquisition>

\section{End Matter}

\section{Author Contributions and Notes}

M.E. Karasu performed all of the experiments. S. Keeney provided overall supervision and funding acquisition. Figures were prepared by M.E. Karasu and the manuscript was written by M.E. Karasu and S. Keeney. The authors declare no conflict of interest.

\section{Acknowledgments}

We thank P. Romanienko, W. Mark, J. Ingenito, and J. Giacalone (MSKCC Mouse Genetics Core Facility) for generating mutant mice; F. Weis-Garcia (MSKCC Antibody and Bioresource Core Facility) for monoclonal antibody expression; D. Wolgemuth (Columbia University) for generously sharing $\mathrm{Ccne}^{+/-}$animals; C. Claeys Bouuaert (Keeney lab) for critical reading of the manuscript; M. Boekhout and D. Ontoso (Keeney lab) for help with animal handling; N. Fang, M. Turkekul, A. Barlas, and K. Manova-Todorova (MSKCC Molecular Cytology Core Facility) for help with testis histology; and members of Keeney lab for discussion. MSKCC core facilities are supported by NIH cancer center core grant P30 CA008748. This work was supported by the Howard Hughes Medical Institute.

control. Nat. Rev. Mol. Cell Biol. 8:149 doi:10.1038/nrm2105

de Rooij DG, de Boer P (2003) Specific arrests of spermatogenesis in genetically modified and mutant mice. Cytogenet. Genome Res. 103:267-276 doi:10.1159/000076812

de Vries FA et al. (2005) Mouse Sycp1 functions in synaptonemal complex assembly, meiotic recombination, and XY body formation. Genes Dev. 19:1376-1389 doi:10.1101/gad.329705

Evans T, Rosenthal ET, Youngblom J, Distel D, Hunt T (1983) Cyclin: a protein specified by maternal mRNA in sea urchin eggs that is destroyed at each cleavage division. Cell. 33:389-396

Fraune J, Schramm S, Alsheimer M, Benavente R (2012) The mammalian synaptonemal complex: protein components, assembly and role in meiotic recombination. Exp. Cell Res. 318:1340-1346 doi:10.1016/j.yexcr.2012.02.018

Geng Y et al. (2003) Cyclin E ablation in the mouse. Cell. 114:431-443 doi:10.1016/S0092-8674(03)00645-7

Gray S, Cohen PE (2016) Control of Meiotic Crossovers: From Double-Strand 
bioRxiv preprint doi: https://doi.org/10.1101/608315; this version posted April 16, 2019. The copyright holder for this preprint (which was not certified by peer review) is the author/funder, who has granted bioRxiv a license to display the preprint in perpetuity. It is made available under aCC-BY 4.0 International license.

Role of cyclin B3 in mouse spermatogenesis

Break Formation to Designation. Annu. Rev. Genet. 50:175-210 doi:10.1146

Guschin DY, Waite AJ, Katibah GE, Miller JC, Holmes MC, Rebar EJ (2010) A rapid and general assay for monitoring endogenous gene modification. Methods Mol Biol. 649:247-256 doi:10.1007/978-1-60761-753-2_15

Henderson KA, Kee K, Maleki S, Santini PA, Keeney S (2006) Cyclindependent kinase directly regulates initiation of meiotic recombination. Cell. 125:1321-1332 doi:10.1016/j.cell.2006.04.039

Jacobs HW, Knoblich JA, Lehner CF (1998) Drosophila Cyclin B3 is required for female fertility and is dispensable for mitosis like Cyclin B. Genes Dev. 12:3741-3751

Jain D et al. (2018) ketu mutant mice uncover an essential meiotic function for the ancient RNA helicase YTHDC2. eLife. 7 doi:10.7554/eLife.30919

Karasu ME, Bouftas N, Keeney S, Wassmann K (2019) Cyclin B3 promotes anaphase I onset in oocyte meiosis. J. Cell Biol. 218 doi:10.1083/jcb.201808091

Kauppi L, Barchi M, Baudat F, Romanienko PJ, Keeney S, Jasin M (2011) Distinct properties of the XY pseudoautosomal region crucial for male meiosis. Science. 331:916-920 doi:10.1126/science.1195774

Kauppi L, Barchi M, Lange J, Baudat F, Jasin M, Keeney S (2013) Numerical constraints and feedback control of double-strand breaks in mouse meiosis. Genes Dev. 27:873-886 doi:10.1101/gad.213652.113

Kumar R, Bourbon H-MM, de Massy B (2010) Functional conservation of Mei4 for meiotic DNA double-strand break formation from yeasts to mice. Genes Dev. 24:1266-1280 doi:10.1101/gad.571710

Lam I, Keeney S (2015) Mechanism and Regulation of Meiotic Recombination Initiation. Cold Spring Harb Perspect Biol. 7 doi:10.1101/cshperspect.a016634

Li Y et al. (2019) Cyclin B3 is required for metaphase to anaphase transition in oocyte meiosis I. J. Cell Biol. doi:10.1083/jcb.201808088

Libby BJ et al. (2002) The mouse meiotic mutation meil disrupts chromosome synapsis with sexually dimorphic consequences for meiotic progression. Dev. Biol. 242:174-187 doi:10.1006/dbio.2001.0535

Liu D, Matzuk MM, Sung WK, Guo Q, Wang P, Wolgemuth DJ (1998) Cyclin A1 is required for meiosis in the male mouse. Nat. Genet. 20:377-380 doi: $10.1038 / 3855$

Lozano J-CC, Perret E, Schatt P, Arnould C, Peaucellier G, Picard A (2002) Molecular cloning, gene localization, and structure of human cyclin B3. Biochem. Biophys. Res. Commun. 291:406-413 doi:10.1006/bbrc. 2002.6458

Mahadevaiah SK et al. (2001) Recombinational DNA double-strand breaks in mice precede synapsis. Nat. Genet. 27:271-276 doi:10.1038/85830

Malumbres M, Barbacid M (2005) Mammalian cyclin-dependent kinases. Trends Biochem. Sci. 30:630-641 doi:10.1016/j.tibs.2005.09.005

Malumbres M, Barbacid M (2009) Cell cycle, CDKs and cancer: a changing paradigm. Nat. Rev. Cancer. 9:153-166 doi:10.1038/nrc2602

Marcet-Ortega M et al. (2017) p53 and TAp63 participate in the recombinationdependent pachytene arrest in mouse spermatocytes. PLoS Genet. 13 doi:10.1371/journal.pgen.1006845

Margolin G, Khil PP, Kim J, Bellani MA, Camerini-Otero RD (2014) Integrated transcriptome analysis of mouse spermatogenesis. BMC Genomics. 15:39 doi:10.1186/1471-2164-15-39

Martinerie L et al. (2014) Mammalian E-type cyclins control chromosome pairing, telomere stability and CDK2 localization in male meiosis. PLoS Genet. 10 doi:10.1371/journal.pgen.1004165

McKee BD, Yan R, Tsai J-HH (2012) Meiosis in male Drosophila. Spermatogenesis. 2:167-184 doi:10.4161/spmg.21800

Miyata $\mathrm{H}$ et al. (2016) Genome engineering uncovers 54 evolutionarily conserved and testis-enriched genes that are not required for male fertility in mice. Proc. Natl. Acad. Sci. USA 113:7704-7710 doi: $10.1073 /$ pnas. 1608458113

Moens PB, Kolas NK, Tarsounas M, Marcon E, Cohen PE, Spyropoulos B (2002) The time course and chromosomal localization of recombinationrelated proteins at meiosis in the mouse are compatible with models that can resolve the early DNA-DNA interactions without reciprocal recombination. J. Cell Sci. 115:1611-1622

Nguyen TB et al. (2002) Characterization and expression of mammalian cyclin b3, a prepachytene meiotic cyclin. J Biol Chem. 277:41960-41969 doi: $10.1074 /$ jbc.M203951200

Ortega S et al. (2003) Cyclin-dependent kinase 2 is essential for meiosis but not for mitotic cell division in mice. Nat. Genet. 35:25-31 doi:10.1038/ng1232

Pacheco S, Marcet-Ortega M, Lange J, Jasin M, Keeney S, Roig I (2015) The ATM signaling cascade promotes recombination-dependent pachytene arrest in mouse spermatocytes. PLoS Genet. 11 doi:10.1371/journal.pgen.1005017

Papanikos F et al. (2018) ANKRD31 regulates spatiotemporal patterning of meiotic recombination initiation and ensures recombination between heterologous sex chromosomes in mice. bioRxiv DOI: https://doi.org/10.1101/423293. doi:DOI: https://doi.org/10.1101/423293.

Refik-Rogers J, Manova K, Koff A (2006) Misexpression of cyclin B3 leads to aberrant spermatogenesis. Cell Cycle. 5:1966-1973 doi:10.4161/cc.5.17.3137

Robert T, Nore A, Brun C, Maffre C, Crimi B, Bourbon HMM, de Massy B (2016) The TopoVIB-Like protein family is required for meiotic DNA double-strand break formation. Science. 351:943-949 doi:10.1126/science.aad5309

Roig I, Dowdle JA, Toth A, de Rooij DG, Jasin M, Keeney S (2010) Mouse TRIP13/PCH2 is required for recombination and normal higher-order chromosome structure during meiosis. PLoS Genet. 6 doi:10.1371/journal.pgen.1001062

Romanienko PJ et al. (2016) A Vector with a Single Promoter for In Vitro Transcription and Mammalian Cell Expression of CRISPR gRNAs. Plos One. 11 doi:10.1371/journal.pone. 0148362

Stanzione $M$ et al. (2016) Meiotic DNA break formation requires the unsynapsed chromosome axis-binding protein IHO1 (CCDC36) in mice. Nat. Cell Biol. 18:1208-1220 doi:10.1038/ncb3417

Sutton KA, Jungnickel MK, Florman HM (2008) A polycystin-1 controls postcopulatory reproductive selection in mice. Proc. Natl. Acad. Sci. USA 105:8661-8666 doi:10.1073/pnas.0800603105

Tang J-X et al. (2018) CRISPR/Cas9-mediated genome editing induces gene knockdown by altering the pre-mRNA splicing in mice. BMC Biotechnol. 18 doi:10.1186/s12896-018-0472-8

Wasmuth EV, Lima CD (2012) Exo- and endoribonucleolytic activities of yeast cytoplasmic and nuclear RNA exosomes are dependent on the noncatalytic core and central channel. Mol Cell. 48:133-144 doi:10.1016/j.molcel.2012.07.012

Wolgemuth DJ, Manterola M, Vasileva A (2013) Role of cyclins in controlling progression of mammalian spermatogenesis. Int J Dev Biol. 57:159-168 doi:10.1387/ijdb.130047av

Wolgemuth DJ, Roberts SS (2010) Regulating mitosis and meiosis in the male germ line: critical functions for cyclins. Philosophical Transactions of the Royal Society of London. Series B, Biological Sciences 365:1653-1662 doi: $10.1098 /$ rstb.2009.0254

Xu J, Li X, Song W, Wang W, Gao S (2019) Cyclin Cyc2p is required for micronuclear bouquet formation in Tetrahymena thermophila. Sci China Life Sci. doi:10.1007/s11427-018-9369-3

Yokoo R, Zawadzki KA, Nabeshima K, Drake M, Arur S, Villeneuve AM (2012) COSA-1 reveals robust homeostasis and separable licensing and reinforcement steps governing meiotic crossovers. Cell. 149:75-87 doi:10.1016/j.cell.2012.01.052 
bioRxiv preprint doi: https://doi.org/10.1101/608315; this version posted April 16, 2019. The copyright holder for this preprint (which was not certified by peer review) is the author/funder, who has granted bioRxiv a license to display the preprint in perpetuity. It is made available under aCC-BY 4.0 International license.

Karasu and Keeney, April 12, 2019 - bioRxiv preprint v1

a

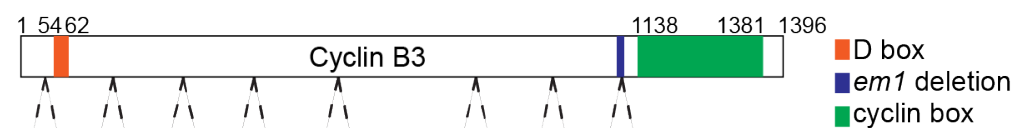

$\begin{array}{llllllllllll}1 & 1 & 1 & 1 & 1 & 1 & 1 & 1 & 1 & 1\end{array}$

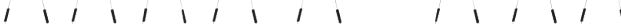

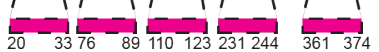

$\begin{array}{lllll}\# 4 & \# 9 & \# 7 & \# 3 & \# 2\end{array}$

111111

$\begin{array}{llllllll}\# 16 & \# 13 & \# 11 & \# 8 & \# 14 & \# 1 & \# 6 & \# 5 \\ & \# 22 & \# 18 & \# 12 & & \# 10 & \# 20 & \# 17\end{array}$

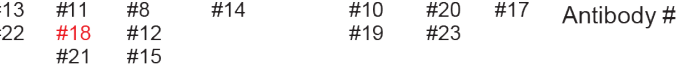

cyclin box

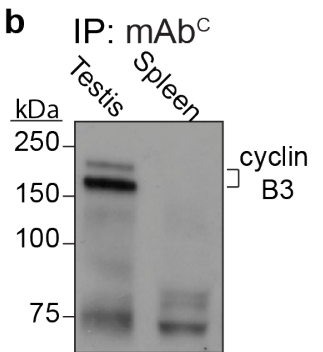

WB: $m A b^{N}$

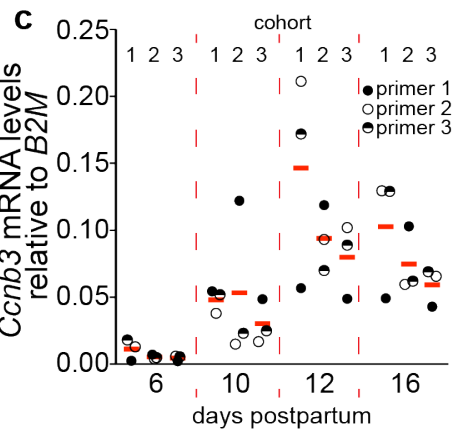

20-33 NKITPREEQQSEKI

76-89 IELKSHVSKRTKKG 110-123 SNMEKEFILDIPNK 231-244 HVVQEEKPVIQEKS 361-374 PVTYENEPMSSKKS 768-781 NENTSSDVDEPLSH 969-982 ENSSNKKANPMDSL 1067-1080 ESRTDNSISAIMPSS

d

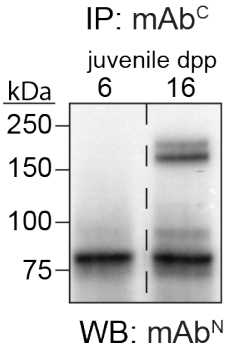

Figure 1: Antibody generation and cyclin B3 expression in the first wave of spermatogenesis

a) Schematic of cyclin B3 showing the cyclin box domain (green) and the destruction box (orange). The positions and sequences of the peptides used to raise antibodies are shown.

b) IP-WB for endogenous cyclin B3 in extracts of testis or spleen from adults. Lower molecular weight bands (around $75 \mathrm{kDa}$ ) are independent of tissue origin and are presumably from immunoglobulin and other proteins in the IP antiserum.

c) RT-qPCR analysis of whole testis RNA extracted from $6,10,12,16$ dpp juvenile animals. Three different primer pairs were used to amplify $C c n b 3$, and three cohorts of littermates were analyzed. The plotted values were the expression levels of Ccnb3 normalized to B2M. The red lines are means across primer pairs.

d) IP-WB for cyclin B3 in extracts from testes of juvenile mice at 6 or $16 \mathrm{dpp}$. The dashed line indicates where the blot image was spliced to remove irrelevant lanes. 
bioRxiv preprint doi: https://doi.org/10.1101/608315; this version posted April 16, 2019. The copyright holder for this preprint (which was not certified by peer review) is the author/funder, who has granted bioRxiv a license to display the preprint in perpetuity. It is made available under aCC-BY 4.0 International license.

Role of cyclin B3 in mouse spermatogenesis

a

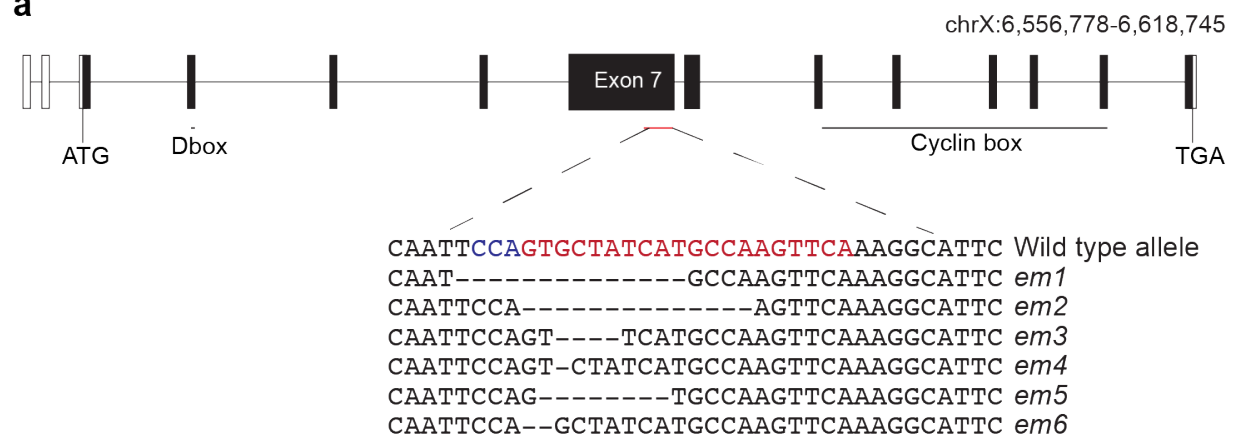

b
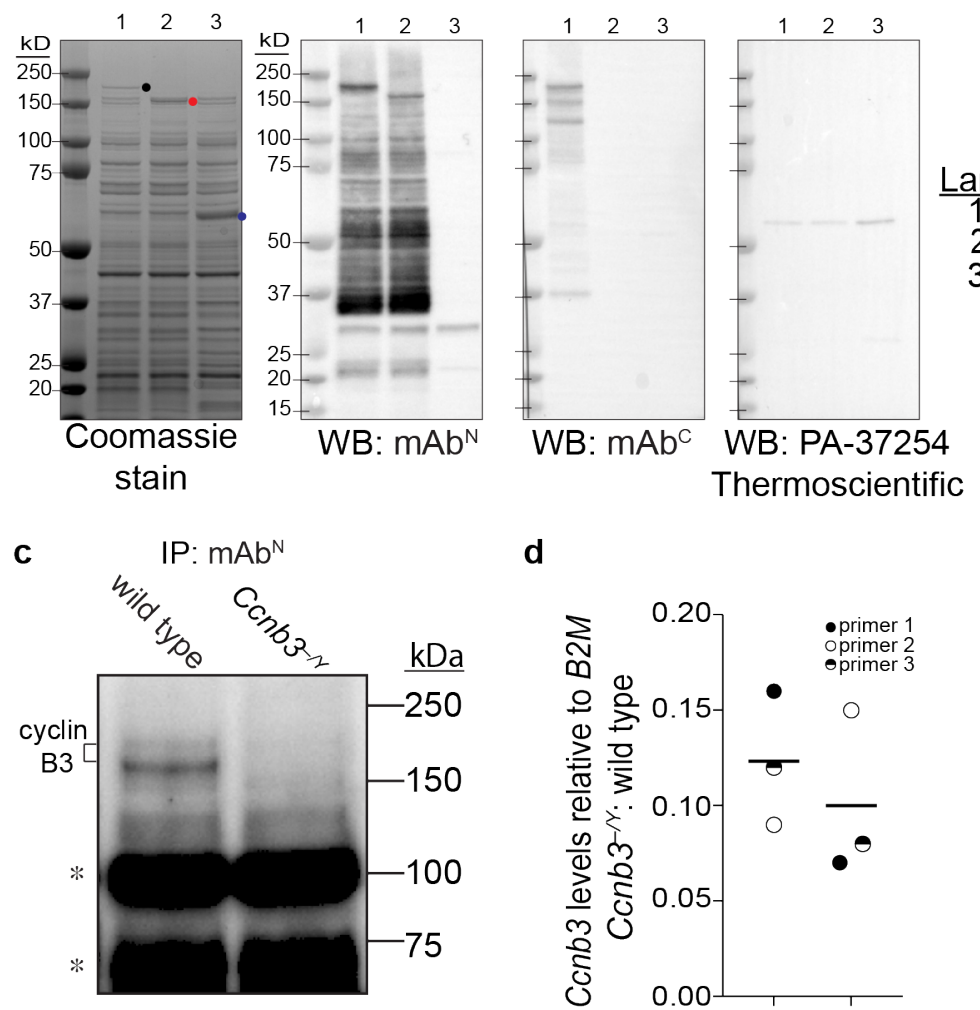

d

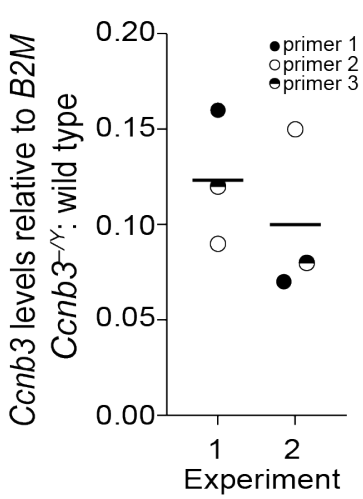

Figure 2: CRISPR/Cas9-mediated Ccnb3 allele generation and confirmation

a) $C c n b 3$ gene diagram. Open boxes show $5^{\prime}$ and $3^{\prime}$ untranslated regions and filled boxes show the coding regions. The CRISPR-Cas9 targeted position is indicated with protospacer adjacent motif (PAM) in blue and single guide RNA sequence in red. Sequences are shown for six em alleles recovered. The em 1 allele was characterized in this study and Karasu et al. 2019.

b) Expression and detection of recombinant cyclin B3 proteins. Constructs contained either full-length coding sequence or the 14-bp deletion of the eml allele fused to the Sumo-His6 tag (Wasmuth and Lima 2012). Zebrafish cyclin B3 was used as a negative control for detection by WB. Proteins were expressed in E. coli and equal aliquots of soluble extracts were fractionated on SDS-PAGE and stained with Coomassie blue or analyzed by WB with the indicated antibody. Dots indicate positions of the largest detected proteins encoded by each construct. Lower molecular weight bands detected by WB with $\mathrm{mAb} \mathrm{b}^{\mathrm{N}}$ or $\mathrm{mAb} \mathrm{b}^{\mathrm{C}}$ presumably are proteolytic fragments and/or products of premature translation termination.

c) IP-WB for cyclin B3. Whole testis extracts from $C c n b 3^{-/ Y}$ and wild-type adults were analyzed using mAb ${ }^{\mathrm{N}}$. Note that IP-WB using only this antibody is less sensitive and gives higher background than when combining $\mathrm{mAb}^{\mathrm{N}}$ with $\mathrm{mAb}($ Fig 1b). Asterisks indicate lower molecular weight bands independent of genotype, possibly from immunoglobulin and other contaminants in the IP elute.

d) RT-qPCR analysis of whole testis RNA extracted from $C c n b 3^{-/ Y}$ and wild-type adults. The plotted values represent the fold difference between mutant and wild type for $C c n b 3$ levels normalized to $B 2 M$. Three different pairs of $C c n b 3$ primers were used. Two independent experiments were performed, each containing a separate mutant-wild type pair. Lines indicate means for each experiment. 
bioRxiv preprint doi: https://doi org/10.1101/608315; this version posted April 16, 2019. The copyright holder for this preprint (which was not certified by peer review) is the author/funder, who has granted bioRxiv a license to display the preprint in perpetuity. It is made available under aCC-BY 4.0 International license.

Karasu and Keeney, April 12, 2019 - bioRxiv preprint v1

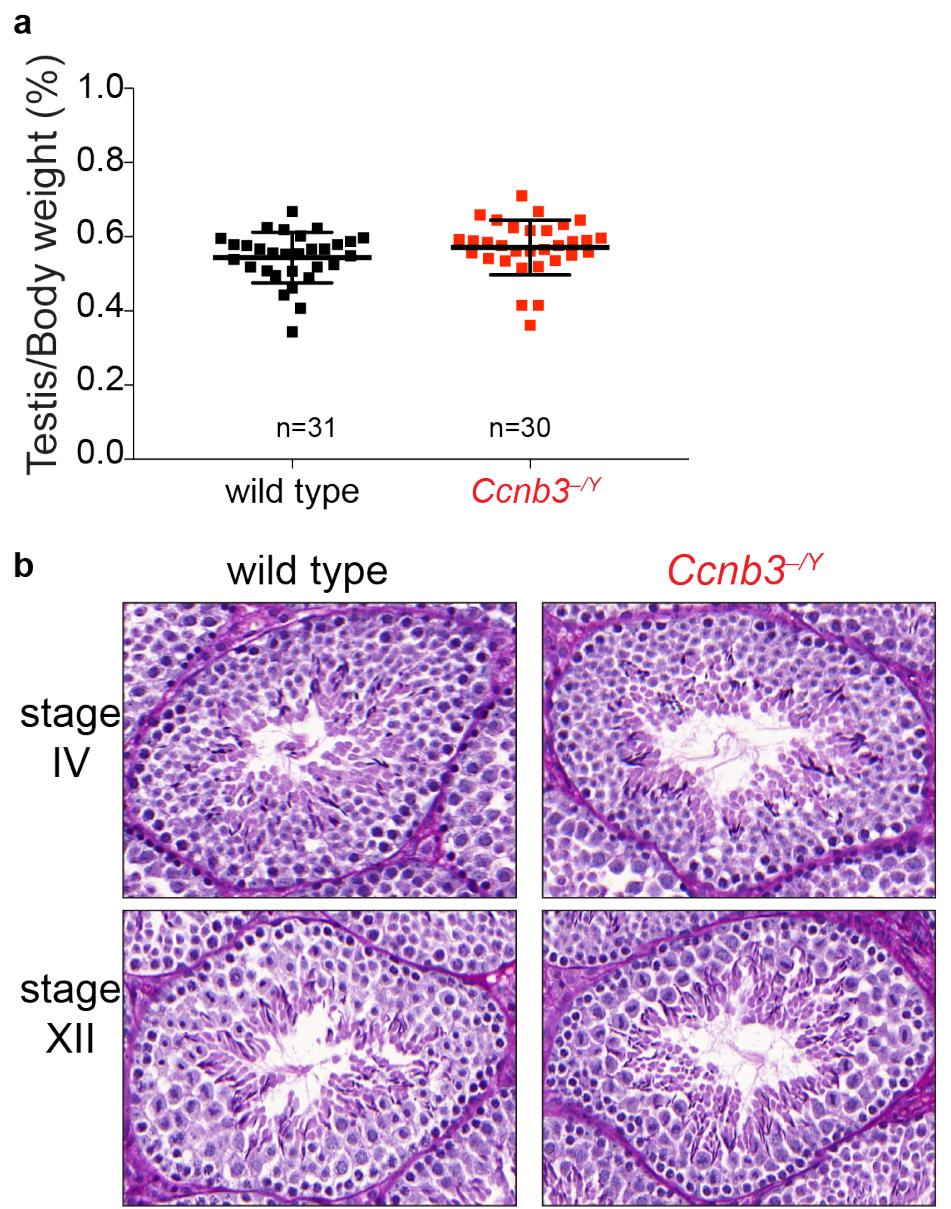

Figure 3: Genetic ablation of Ccnb3 did not affect testis size or seminiferous tubule structure

a) Testis-to-body weight ratios (percent) for adult mice. Error bars indicate means \pm standard deviation: $0.54 \pm 0.068$ and $0.57 \pm 0.070$ for wild type and $C c n b 3^{-/ Y}$, respectively.

b) Representative periodic acid Schiff stained seminiferous testis sections from adult mice. Stages IV and XII are the stages most commonly associated with apoptosis of spermatocytes encountering meiotic defects (Ahmed and de Rooij 2009). 
bioRxiv preprint doi: https://doi.org/10.1101/608315; this version posted April 16, 2019. The copyright holder for this preprint (which was not certified by peer review) is the author/funder, who has granted bioRxiv a license to display the preprint in perpetuity. It is made available under aCC-BY 4.0 International license.

Role of cyclin B3 in mouse spermatogenesis
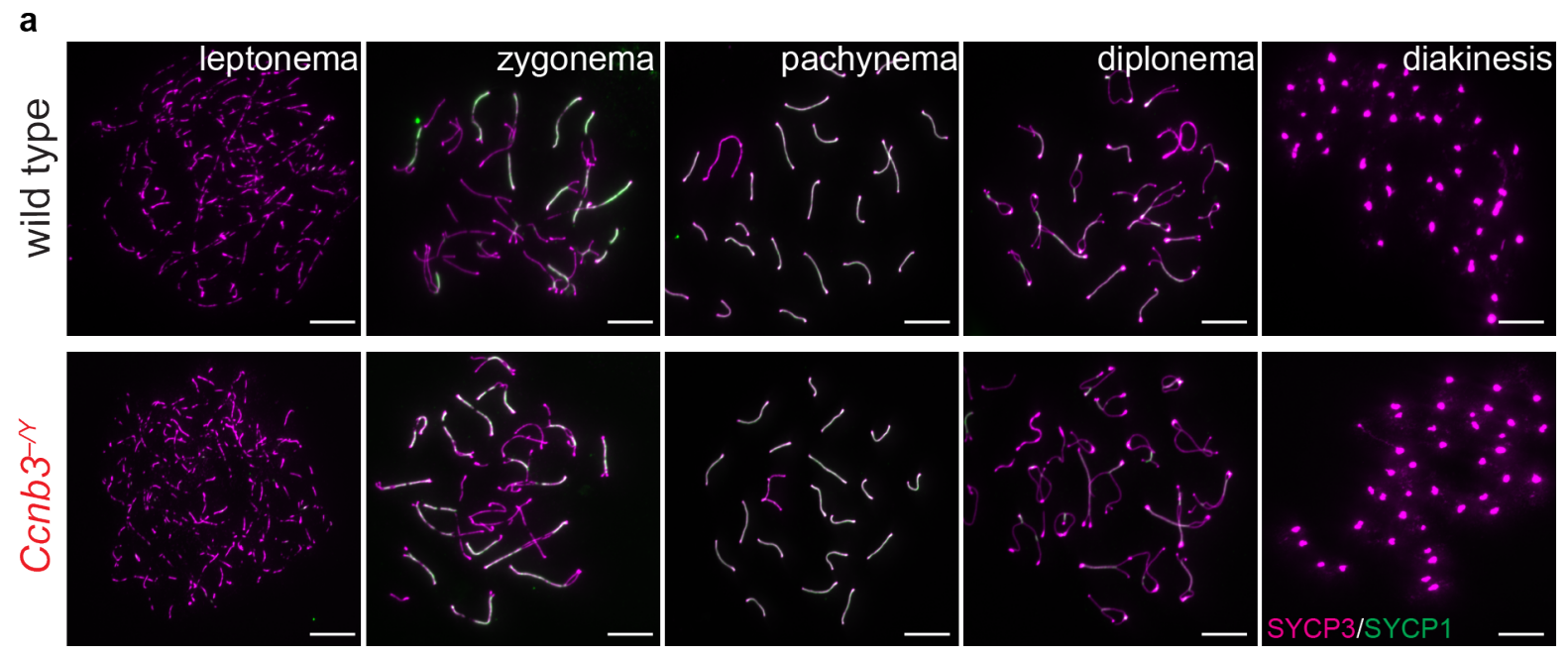

b
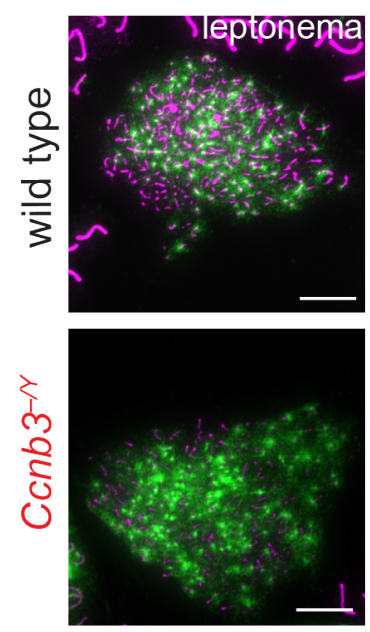
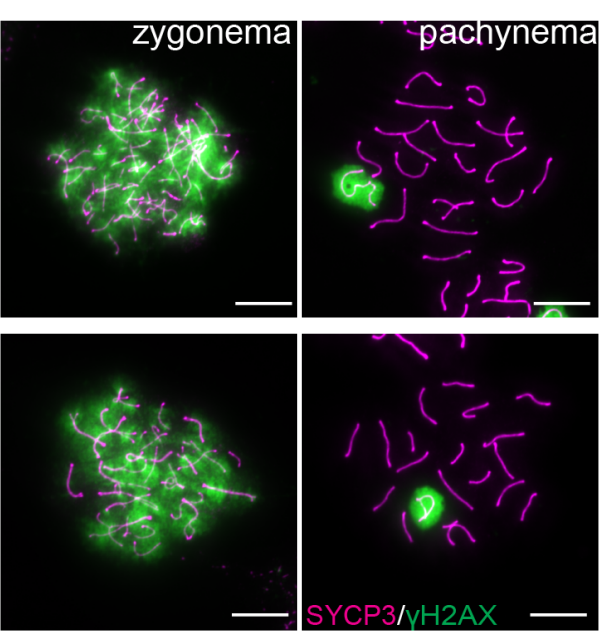

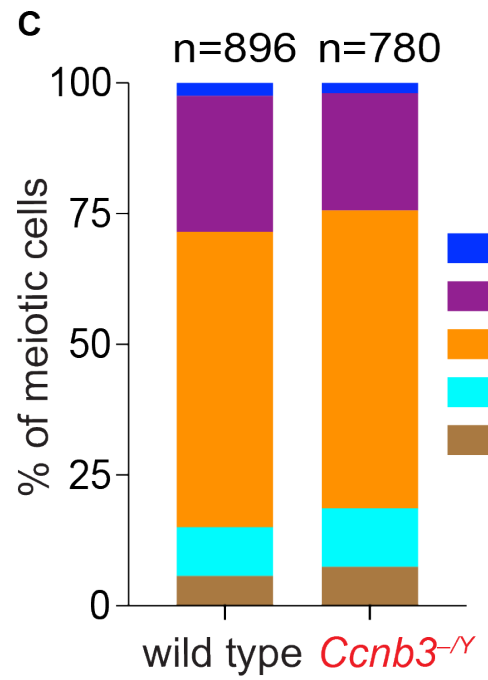

Figure 4: Meiotic Progression is normal in $\mathrm{Ccnb}^{-/ Y}$ males

a) Representative images of meiotic prophase stages. Meiotic spreads from wild type and $C c n b 3^{-/ Y}$ males were stained with $\mathrm{SYCP} 3$ and $\mathrm{SYCP} 1$ antibodies. Scale bars represent $10 \mu \mathrm{m}$.

b) Representative images of meiotic spreads stained with SYCP3 and $\gamma \mathrm{H} 2 \mathrm{AX}$ antibodies. Scale bars represent $10 \mu \mathrm{m}$.

c) Distribution of meiotic prophase stages. Two mice for each genotype were analyzed. Meiotic cells are defined as follows. Leptonema: short patches of SYCP3 and $\gamma \mathrm{H} 2 \mathrm{AX}$ staining on autosomes; zygonema: some synapsed homolog stretches and $\gamma \mathrm{H} 2 \mathrm{AX}$ staining on autosomes; pachynema: fully synapsed homologs and $\gamma \mathrm{H} 2 \mathrm{AX}$ staining only on sex body; diplonema: desynapsed homologs and $\gamma \mathrm{H} 2 \mathrm{AX}$ staining only on sex body; diakinesis: $\mathrm{SYCP} 3$ on centromeres and no $\gamma \mathrm{H} 2 \mathrm{AX}$ staining. 
bioRxiv preprint doi: https://doi.org/10.1101/608315; this version posted April 16, 2019. The copyright holder for this preprint (which was not certified by peer review) is the author/funder, who has granted bioRxiv a license to display the preprint in perpetuity. It is made available under aCC-BY 4.0 International license.

Karasu and Keeney, April 12, 2019 - bioRxiv preprint v1
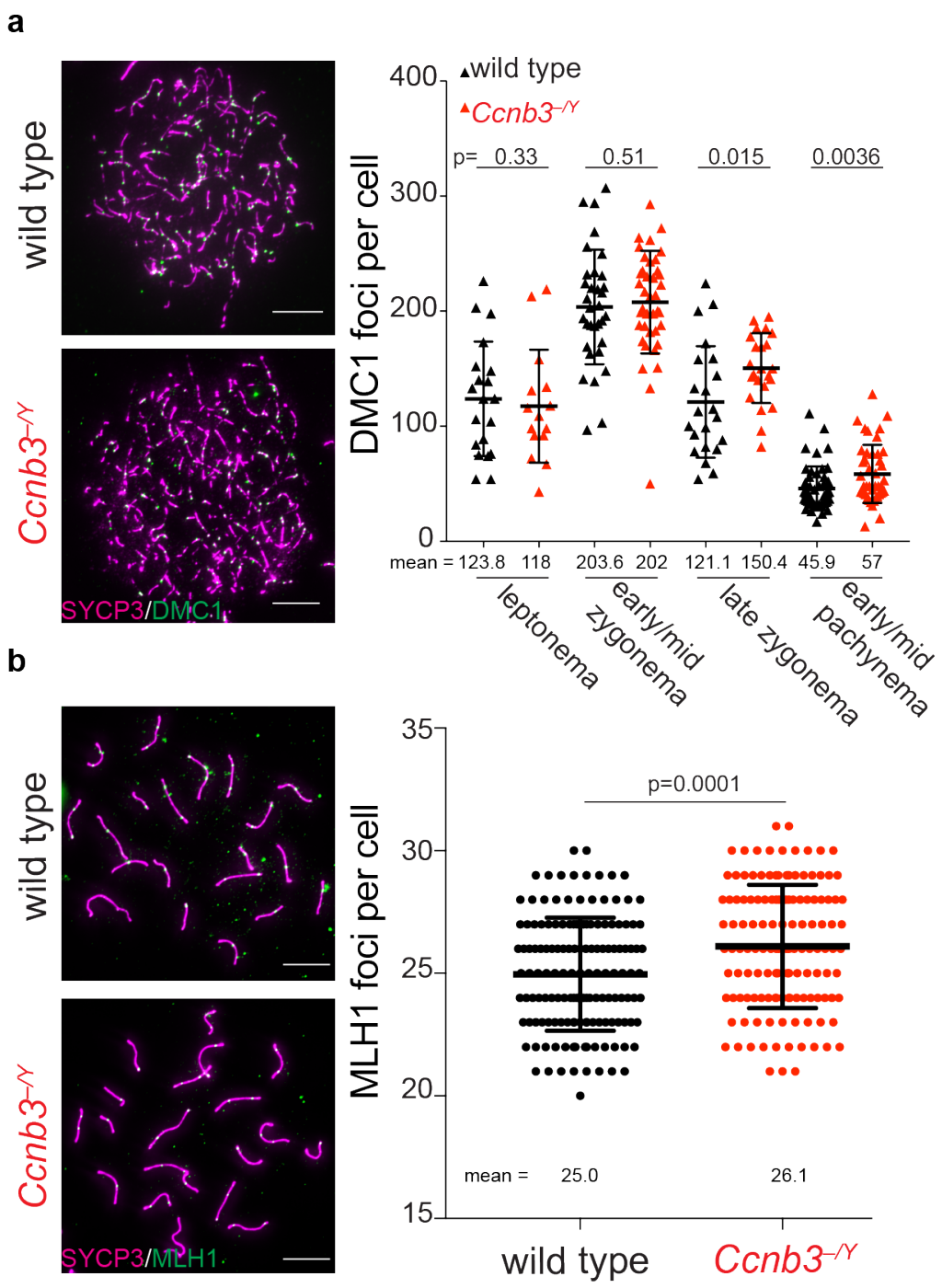

Figure 5: DMC1 and MLH1 focus numbers in $\mathrm{Ccnb}^{-/ Y}$ males

a) Representative images (left) and quantification (right) of meiotic spreads stained with DMC1 and SYCP3 antibodies. Scale bars represent $10 \mu \mathrm{m}$. b) Representative images (left) and quantifications (right) of meiotic spreads stained with MLH1 and SYCP3 antibodies. Scale bars represent $10 \mu \mathrm{m}$. Error bars indicate means \pm standard deviation; $p$ values are from Student's t tests. 
bioRxiv preprint doi: https://doi.org/10.1101/608315; this version posted April 16, 2019. The copyright holder for this preprint (which was not certified by peer review) is the author/funder, who has granted bioRxiv a license to display the preprint in perpetuity. It is made available under aCC-BY 4.0 International license.

Role of cyclin B3 in mouse spermatogenesis

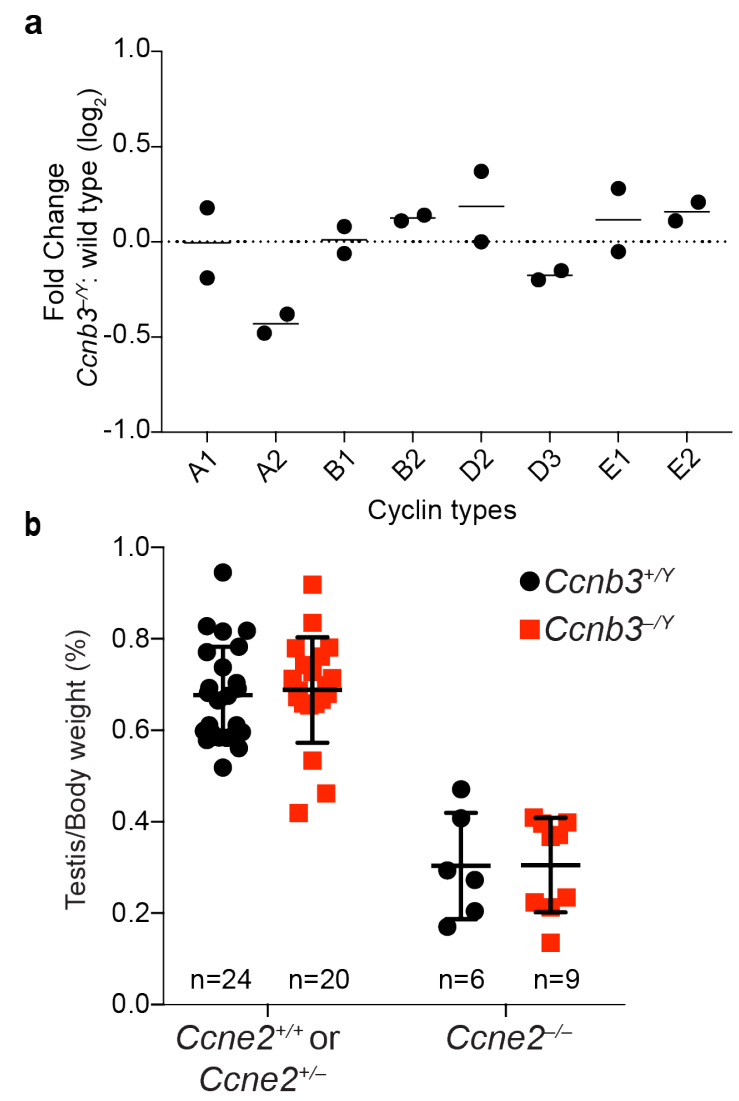

C
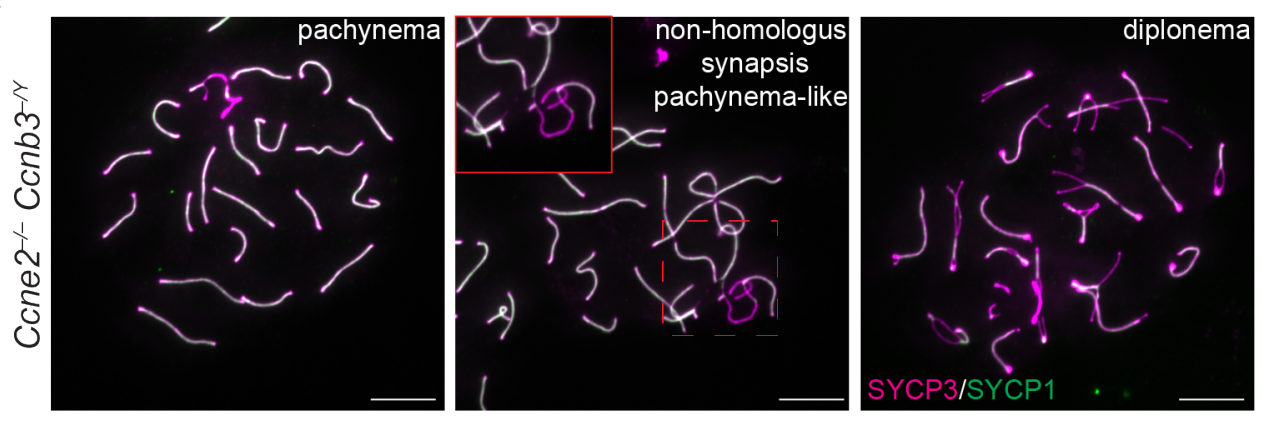

Figure 6: Testing for redundancy with other cyclins

a) RT-qPCR analysis of whole testis RNA extracted from $C c n b 3^{-/ Y}$ and wild-type adults. The plotted values represent the $\log _{2}$ fold difference between mutant and wild type for levels of the indicated cyclin mRNA normalized to $B 2 M$. Two independent experiments were conducted, each containing a separate mutant-wild type pair. Black lines represent the means.

b) Testis-to-body weight ratios (percent) for adult mice. Error bars indicate means \pm standard deviation for $C c n e 2^{+/+}$or $C c n e 2^{+/-} C c n b 3^{+/ Y}: 0.68 \pm$

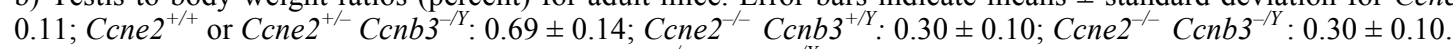

c) Representative images of meiotic spreads $C c n e 2^{-/}, C c n b 3^{-/ Y}$ spermatocytes stained with SYCP3 and SYCP1 antibodies. Inset shows an example of abnormal synapsis between homologs. Scale bars represent $10 \mu \mathrm{m}$. 
bioRxiv preprint doi: https://doi.org/10.1101/608315; this version posted April 16, 2019. The copyright holder for this preprint (which was not certified by peer review) is the author/funder, who has granted bioRxiv a license to display the preprint in perpetuity. It is made available under aCC-BY 4.0 International license.

Karasu and Keeney, April 12, 2019 - bioRxiv preprint v1

a
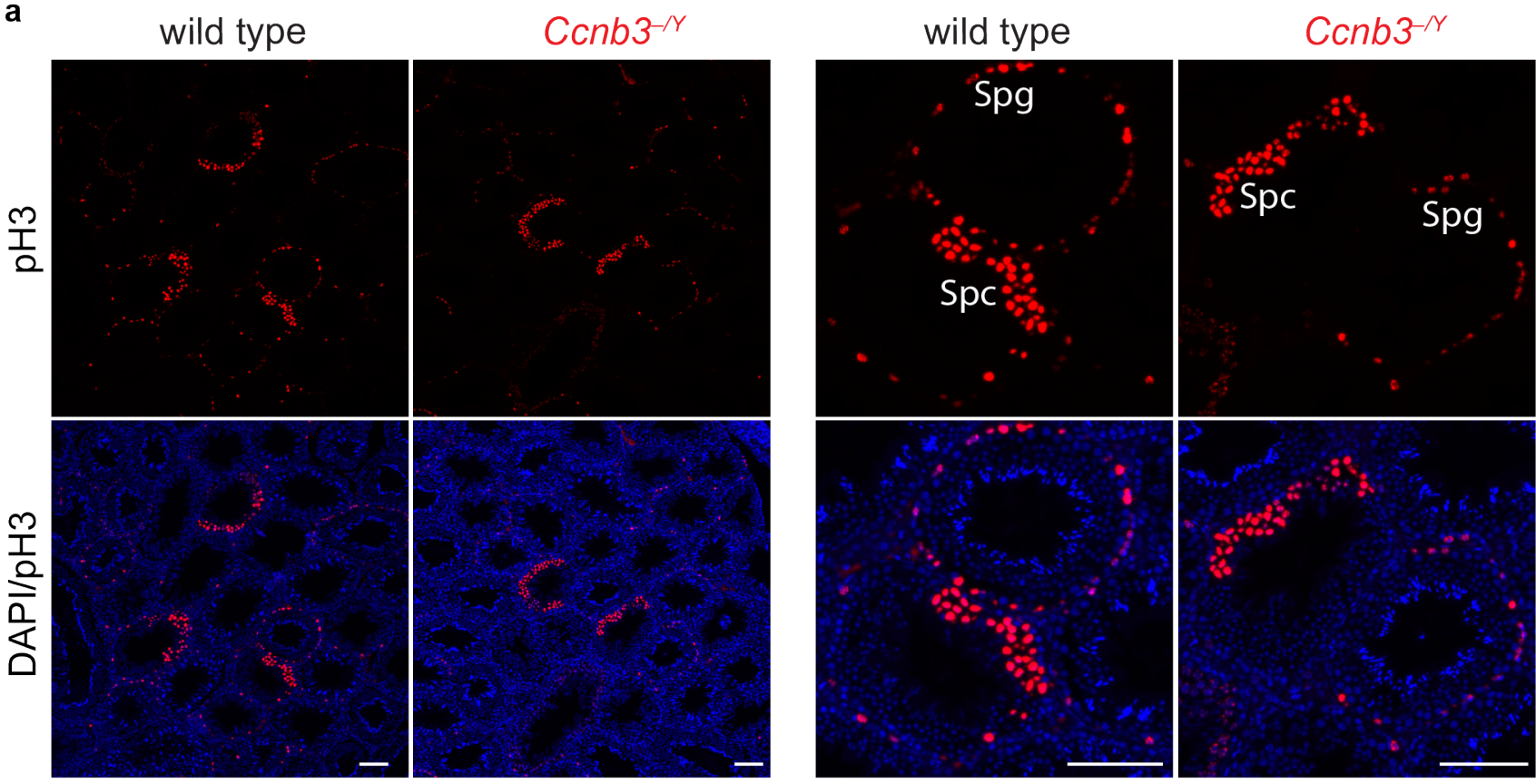

b

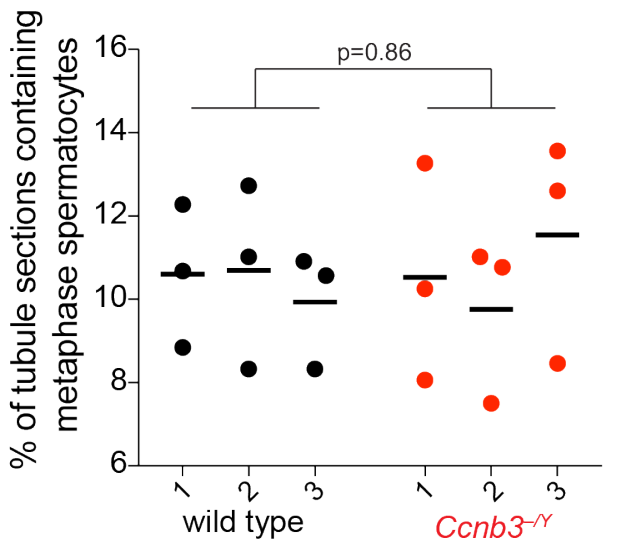

Figure 7: No apparent accumulation of metaphase spermatocytes in Ccnb3 ${ }^{-/ Y}$ males

a) Representative $\mathrm{pH} 3$-stained testis sections from wild type and $C \mathrm{cnb} 3^{-/ Y}$ (lower magnification views at left; higher magnification at right). Anti-pH3 also stains mitotically dividing spermatogonia, which are easily recognized because they are located at the periphery of the tubules; these were excluded from the counting. Spg: spermatogonia, Spc: spermatocytes. Scale bar represents $100 \mu \mathrm{m}$.

b) Quantification of tubules containing meiotically dividing cells. Each point is the value from one testis section. Three sections were scored from each of three different animals per genotype. Lines indicate means for each animal. The $\mathrm{p}$ value is from a Student's $\mathrm{t}$ test performed on data pooled for each genotype. 
Cyclin B3 is dispensable for mouse spermatogenesis.

Mehmet E. Karasu and Scott Keeney

\section{Supplemental Table S1. Oligonucleotides}

\begin{tabular}{|c|c|c|}
\hline Primer & Forward 5' to $3^{\prime}$ & Reverse $5^{\prime}$ to $3^{\prime}$ \\
\hline CCNB3-A/B & GAGTATTAGCACTGAGTCAGGGAC & GGAATACCTCAGTTTCTTTTGCAC \\
\hline GT4-F/R & TGTTGATGAAGAGGAATTTTTCAAATCATTCCT & TTCTTTTGCACCCAGAGTTGACTTAAAG \\
\hline E2-L/G & GCTATAGCAGTTGTTTCTGTTTG & GGTTCTCCCATTTAGAGCACAG \\
\hline E2-L/3 & GCTATAGCAGTTGTTTCTGTTTG & GATCTCTCGTGGGATCATTG \\
\hline$E 2-3 / 4$ & CCAGTAATTGCAAGTTGGAGTTGGA & TGTGGTTCCAGGTCAGAATGCA \\
\hline Ccnb3-1 & CCACTACTTACATGATTGCAGCC & AGGATGCTGCTTTCCAAAGAT \\
\hline Ccnb3-2 & AAAGGCATTCAATCCTGTCG & GGATCTTGGCCTTCCTTTTC \\
\hline Ccnb3-3 & GCGTAGATATGCTTCGTGCATC & AGGCTGCAGCTAGCTTTGAA \\
\hline Cona1 & TGGACAGGTTTCTCTCCTGC & CGGGCGGATATATCTCTTCA \\
\hline Ccna2 & TTACCCGGAGCAAGAAAACC & TTCATTAACGTTCACTGGCTTG \\
\hline Conb1 & GGCTGACCCAAACCTCTGTA & TCCAGTCACTTCACGACCCT \\
\hline Conb2 & AGCCTCTGTGAAACCAGTGC & TGCAGAGCAGAGCATCAGAG \\
\hline Cone1 & GTGGCTCCGACCTTTCAGTC & CACAGTCTTGTCAATCTTGGCA \\
\hline Ccne2 & AGGAATCAGCCCTTGCATTATC & CCCAGCTTAAATCTGGCAGAG \\
\hline Cond2 & CGCAGACCTTCATCGCTC & CTGCTGAAGCCCACAGATG \\
\hline Cond3 & TGCATCTATACGGACCAGGC & AATCAAGGCCAGGAAGTCGT \\
\hline B2M & ACACTGAATTCACCCCСАCTGA & CGATCCCAGTAGACGGTCTTGG \\
\hline $\begin{array}{l}\text { pGBKT7 } \\
\text { cyclin B3: }\end{array}$ & $\begin{array}{l}\text { CATGGAGGCCGAATTCATGCCACCACCACTACTA } \\
\text { CCC }\end{array}$ & $\begin{array}{l}\text { GGATCCCCGGGAATTCTCAGTGGAATAATGCA } \\
\text { CAATTCAAAAG }\end{array}$ \\
\hline $\begin{array}{l}\text { pRSF-DUET } \\
\text { cyclin B3: }\end{array}$ & $\begin{array}{l}\text { ACAGATTGGTGGATCCATGCCACCACCACTACTA } \\
\text { CCC }\end{array}$ & $\begin{array}{l}\text { CCGCAAGCTTGTCGATCAGTGGAATAATGCAC } \\
\text { AATTC }\end{array}$ \\
\hline $\begin{array}{l}\text { pRSF-DUET } \\
\text { cyclin B3 } \\
\Delta 14 \mathrm{bp}\end{array}$ & ATTGTCTGTTCTGGATTCAAAAGCATTGCTG & GCCAAGTTCAAAGGCATTCAATCCTG \\
\hline $\begin{array}{l}\text { pRSF-DUET } \\
\text { zebrafish } \\
\text { cyclin B3: }\end{array}$ & $\begin{array}{l}\text { ACAGATTGGTGGATCCATGCCGTTTTTCAAAAGGA } \\
\text { AAAAAGC }\end{array}$ & $\begin{array}{l}\text { GCTCGAATTCGGATCCTCACTTCAAAAGCCCTT } \\
\text { CAAGC }\end{array}$ \\
\hline
\end{tabular}




\section{Supplemental Table S2. Antibodies}

\section{A. Primary Antibodies:}

\begin{tabular}{l|lll|lll}
\hline Target & $\begin{array}{l}\text { Amount for } \\
\text { IP }\end{array}$ & $\begin{array}{l}\text { Dilution for } \\
\text { WB }\end{array}$ & $\begin{array}{l}\text { Dilution } \\
\text { for IF/IHC* }\end{array}$ & Host & Supplier & Catalog \\
\hline $\begin{array}{l}\text { Cyclin B3- } \\
\text { mAB }\end{array}$ & $10 \mu \mathrm{g}$ & $1: 1000-3000$ & N/A & Mouse & Abmart & C517 \\
\hline $\begin{array}{l}\text { Cyclin B3- } \\
\text { mAB }\end{array}$ & $2 \mu \mathrm{g}$ & $1: 1000-3000$ & N/A & Mouse & Abmart & C500 \\
\hline Cyclin B3 & N/A & $1: 1000$ & N/A & Rabbit & Thermoscientific & PA5-37254 \\
\hline SYCP3 & N/A & N/A & $1: 200$ & Mouse & Santa Cruz & sc-74569 \\
\hline YH2AX & N/A & N/A & $1: 500$ & Rabbit & Santa Cruz & sc-101696 \\
\hline DMC1 & N/A & N/A & $1: 100$ & Rabbit & Santa Cruz & sc-22768 \\
\hline SYCP1 & N/A & N/A & $1: 100$ & Rabbit & Abcam & ab15090 \\
\hline MLH1 & N/A & N/A & $1: 25$ & Rabbit & Calbiochem & pc56 \\
\hline pH3 & N/A & N/A & $1 \mu \mathrm{g} / \mathrm{ml}$ & Rabbit & Upstate & $06-570$ \\
\hline
\end{tabular}

\section{B. Secondary Antibodies:}

\begin{tabular}{llllll}
\hline Target & $\begin{array}{l}\text { Dilution for } \\
\text { WB }\end{array}$ & $\begin{array}{l}\text { Dilution } \\
\text { for IF/lHC* }\end{array}$ & Host & Supplier & Catalog \\
\hline anti-mouse & N/A & $1: 400$ & Donkey & Life Technologies & A21203 \\
\hline anti-rabbit & N/A & $1: 400$ & Donkey & Thermofisher Scientific & R37118 \\
\hline anti-mouse & $1: 10000$ & & Goat & Biorad & 1721011 \\
\hline anti-rabbit & $1: 10000$ & & Goat & Biorad & 1706515 \\
\hline anti-rabbit & N/A & $1: 200$ & Goat & Vector Labs & BA-1000 \\
\hline
\end{tabular}

${ }^{*} \mathrm{IF} / \mathrm{IHC}$, immunofluorescence or immunohistochemistry. 